\title{
ELISHA PARKER'S “MINUTES"-AN EIGHTEENTH CENTURY RECORD OF THE PARKER FAMILY
}

\author{
BY ANNE ZIMMER
}

Mrs. ZImMer is a graduate student in American History at Wayne State University, with a special interest in eighteenth century studies.

$\mathrm{U}$

NDER the full title "Minutes of Transactions Relating to the Estate of John Parker Beginning in March, I 748," Elisha Parker recorded his effort to straighten out the longneglected estate of his deceased parents, John and Jennett Parker. He terminated it just a few months before his untimely death at twenty-seven. The unpublished manuscript is in the Special Collections of the Rutgers University Library.

Parker's journal of financial transactions provides a basis for a consideration of the problems of land-holding in colonial New Jersey, the acute currency shortage endemic to all the colonies, and the ingenious innovations of "barter-bookkeeping." The record also indirectly contributes to the genealogy of the Parker family, and succinctly illustrates a pattern of living in the eighteenth century when monetary problems affected family groups and the colonial government. The shortage of currency was a chronic problem in New Jersey as it was in all the colonies, and Elisha's "Minutes" reflect the economic difficulties of the time. The Loan Office had been created by the provincial government to ease the scarcity by lending money with land as collateral. John Parker had been one of the Loan Commissioners of this "Land Bank." The Parkers owned numerous parcels of land and had mercantile interests. In the absence of commercial banks, the Parkers appear to have loaned money out at interest, as Elisha's journal and the family wills indicate.

Land title problems and the Elizabethtown Riots in particular were serious in the years during which Elisha kept his record, and he was involved in two ways. One parcel of land belonging to the Parker estate was in the disputed Elizabethtown patent. The 
"Minutes" indicate an agreement drawn up by Elisha to satisfy the purchaser's demand for protection against an unclear title. ${ }^{1}$ His second involvement was as attorney for the Board of Proprietors which was actively evicting Elizabethtown patentees who were ostensibly infringing on Proprietary property. The growing intransigence of the colonists in this area may be seen as early as 1672 , possibly because of its heterogeneous population, diversity of religion in East New Jersey, and the "yankee spirit" brought in by individualistic migrants from New England towns.

The "Minutes" also show the rampant inflation and monetary differences among the colonies, specifically New Jersey and New York. The journal mirrors, too, the commonly accepted principles of accounting of that period. There were few professional bookkeepers then, and Elisha, with his legal training, was probably better than most. But he, like the rest, was free of certain requirements. No one had to calculate a profit statement for the year, nor figure an expense account, nor were books closed off at the end of a specific period. In short, accounting was viewed as a series of relationships, usually extending over a long period of time. ${ }^{2}$ This attitude is particularly true of Elisha's record, which involved many long-term real estate and mortgage arrangements. These relationships could become exceedingly complex, as excerpts from the manuscript reveal.

Elisha Parker envisioned his "Minutes" simply as a neat record for one of the executors of the estate, Andrew Johnston, his uncle; but it is an excellent example of the principles of negotiation prevalent then, for opening the books to disputant debtors and creditors was common, as was arbitration with a third party.

The journal acquires additional meaning when its author, his family, and the circumstances of his record-keeping are known. More than two hundred years ago, Elisha returned from New York to his family in Perth Amboy, once the hope of the Proprietors that it would become the port city, the "London" of America. He had a new licence to practice law, he was just twenty-one years old, and he was at the threshold of a promising career. Son of John Parker

1 Manuscript entry, April $23,1750$.

2 A. C. Littleton and B. S. Yames, Studies in the History of Accounting (Homewood, Illinois: Richard D. Irwin, Inc., 1956), p. 274. 
(I693-1732) and Jennett Johnston Parker (I699-I74I), Elisha was a member of a very prominent Middlesex County family. They were part of the social elite of Perth Amboy, which revolved around St. Peter's Episcopal Church. ${ }^{3}$ The rector was William Skinner, another family name which meant a passport to society. Elisha's home was the "Stone Castle," sloping down to the Raritan River on property originally acquired by his grandfather, Elisha Parker of Woodbridge. Here at Perth Amboy, John built the "Castle," and brought his bride, Jennett, in I $72 \mathrm{I}$. Jennett was one of the thirteen children of John Johnston. He had more extensive land-holdings than the Parkers, was very prominent in East New Jersey affairs and was, of course, a member of the King's Council. ${ }^{5}$

Elisha could trace his ancestry in New Jersey records back to the year I675, when his grandfather, Elisha, II, took up I 82 acres at Woodbridge, on the road to Piscataway. Woodbridge had been settled by a colony from Newbury, Massachusetts. It is not known for certain what the origins of this Elisha were, but there is an Elisha Parker mentioned in the Annals of Barnstable, Massachusetts, as far back as 1675 , in which year he married Elizabeth Hinckley, the daughter of Samuel, who had migrated to Scituate, Cape Cod, from Tenterden, County Kent, England, in the year I634. The children of this Barnstable couple were Thomas (b. I658) and Elisha, II (b. I660). Speculation that these were the New Jersey Parker antecedents is strengthened by the fact that Elisha of Woodbridge also had children named Thomas and Elisha, of several born to

${ }^{3}$ Proceedings of the New Jersey Historical Society, New Series, V (Newark: New Jersey Historical Society, I920), 75.

${ }^{4}$ Rev. W. Northey Jones, History of St. Peter's Church (Amboy: By the author, 1924), p. 49 .

5Johnston was known as "Doctor," a title of respect he earned when he assumed responsibility on the ship "Henry and Francis" in I685. George Scot, Laird of Pitlochie, Scotland, had been in charge of the cargo of immigrants and had died, with many others, in an epidemic aboard ship. Johnston (known as Johnstone at this time) married Scot's daughter, Eupham, petitioned for Scot's share of the land he was to have received for his services ( 500 acres), then received an additional 30,5 I I acres on his own account. Johnstone had been a druggist in Scotland before his emigration and this fact, plus his ministrations to the sick, gave rise to the title. His children subsequently dropped the "e" from the name. William Whitehead, Contributions to the Early History of Perth Amboy and Adjoining Country with Sketches of Men and Events (New York: Appleton Company, 1856), pp. 68-70. 
his first wife. ${ }^{6}$ This first Elisha to arrive in East Jersey, like many other first settlers, was called "yeoman" in the patent records in I 675, but rose to the rank of "Esquire" as he acquired more property and began the climb through civil offices to the Assembly and then to the Council.

Elisha Parker, born in I 724, keeper of the "Minutes," was sixteen when he went to New York City to study law under the well-known lawyer, James Alexander, considered one of the two most able practicing lawyers in the colonies. William Smith, also of New York, was the other. ${ }^{7}$ Elisha's life in New York until I 745 was that of a diligent student and a sociable young gentleman. ${ }^{8}$ The Alexanders (Mary and James) were wealthy and well-known politically and socially in New Jersey and New York, and had provided the entree to New York society for Elisha. ${ }^{9}$

At home in Perth Amboy, the Parkers and Johnstons were leaders in St. Peter's Church. Andrew Johnston, son of John Johnston, was also a Council Member and a prosperous merchant in Perth Amboy and New York. ${ }^{10}$ Andrew Johnston was one of the executors of the will of his sister, Jennett Parker, and it was for Andrew that Elisha drew up his "Minutes," to record his efforts to pick up the threads of the long-neglected estate. Parker brothers and sisters had intermarried with the affluent Johnston clan. ${ }^{11}$ Elisha's brother, James, was to marry a daughter of the Skinners in 1753 and, as the only surviving

${ }^{6}$ Augustus Parker, Editor, Parker in America: 1630-19 10 (Buffalo: Niagara Frontier Publishing Company, I9Ir), p. 34. Essentially the same material is found in William Benedict, New Brunswick in History (New Brunswick: By the author, I925), pp. I86I 87 .

${ }^{7}$ Herbert Osgood, American Colonies in the Eighteenth Century II (New York: Macmillan Company, 1924), 447.

${ }^{8}$ Excerpts from a sketchy diary he kept of those years appear in the work of Esther Singleton, Social New York Under the Georges (New York: Appleton Company, 1 902), pp. 303-304.

9 Although Elisha lived at a Mrs. Ver Planck's in the Broadway, his time was spent with James Alexander at law during the day, and in the evening he tutored Alexander's son, William, at math. (William later used the title, "Lord Stirling.") The diary mentions Dancing Assemblies, cards, frolics, cock fighting, jaunts to "Morrisania in a slay," and later, marriage to the Alexander's daughter, Catherine. Singleton, Social New York, pp. 303-304.

${ }^{10}$ Jones, History, p. 3 I2; Whitehead, Contributions, p. 72.

11 Orra Eugene Monnette, First Settlers of Ye Plantations of Piscataway and Woodbridge-Olde East New Jersey, I (Los Angeles: Leroy Carman Press, 1934), Io5, I 95. Also New Jersey Archives, First Series, XVI, 9o. See also original manuscript will, John Johnston, Liber LBB, 320-324. 
child of John Parker, he and his issue would remain prominent in New Jersey affairs through the succeeding years.

Of the six members of the King's Council in the year I 748, James Alexander and Andrew Johnston were related by marriage to the Parkers; and two others, Edward Antill and James Hude, were close family friends. There had been a Parker on the Council from the late seventeenth century until the death of Elisha's own father. In a few short years, a Parker would once again be in that privileged group, with the appointment of Elisha's brother, James. Elisha's years in New York had resulted in the extension of the Parker social eminence in that direction, for Catherine Alexander, daughter of James and Mary, came to Perth Amboy as Elisha's bride.

Elisha became an attorney for the Proprietors of New Jersey after his return from New York in $1745 .^{12}$ He returned to a world of challenge, public and private. We know much about his family affairs from the pages of the "Minutes." Elisha anticipated that this work on the estate, the combined holdings of his grandfather of Woodbridge, his father and his mother, all deceased, would take up a major part of his time. His mother had had property in her own right, a one-sixth share of the Johnston estate. But the major problem was that of neglect of family business since the deaths of his parents: John had died in 1732 and Jennett in I74I. Some debts due the Parkers had remained uncollected for as long as sixteen years. Perhaps because of the tumult of political affairs, Andrew Johnston, executor of John's estate along with William Skinner and Robert Hude, apparently did not find the time to manage the Parker estate and his own business affairs. Robert Hude provided information at times, but there is no evidence that William Skinner, the minister, took any active part in helping Elisha. Fortunately, competent hands were ready to take over the management. In 1748 , Elisha was given a bundle of bonds and bills, with a list,

copy of which list with my receipts I

am to give to $\mathrm{Mr}$. Johnston. ${ }^{13}$

And so began his record.

12 The Board of Proprietors established in 1684 at Amboy lost its governmental function in I 702, at Queen Anne's order that New Jersey be governed with New York, but continues in existence to the present day.

13 "Minutes," Entry of March 30, 1748. 
An interesting partnership arrangement concerning the operation of a sawmill at Pine Brook, Monmouth County, claimed Elisha's attention immediately and required several entries. The Parkers had an interest with three others, Samuel Leonard, John Lorton, and Michael Erickson (Arrickson). Erickson managed it in exchange for one-half the profits (his method of bookkeeping was to keep records on the chimney with chalk). The other half was to be divided into one-eighth shares. Each partner was to arrange once a year to meet and ascertain what the debts were and each was to collect his share. Whether it might have worked well or not, the arrangement was complicated by the death of John Parker. From I 732 on, the Executors of the estate did nothing about either the profits or the debts, although Erickson had approached Andrew Johnston about it. Elisha tried to pick up the threads of this long-standing arrangement, since no statute of limitations cancelled debts.

At first, after consulting with the partner, Samuel Leonard, Elisha demanded interest on the profits over all those years. ${ }^{14}$ Erickson protested, and rightly so, since the Parkers had not picked up their share of the debts. However, an amicable arrangement was worked out, and without an outside party. Elisha ultimately found that his father had paid for some boards that Erickson wanted credit for, and thus refused to allow Erickson credit for them again. Since Erickson kept his books with chalk on his chimney piece (having it transferred later to a book by someone who could write), Elisha concluded in an entry in the "Minutes" dated April 4, I 748 that Erickson was honest but that an error had been made in the transfer to the book.

The major difference was worked out after several alternative suggestions. Parker gave up the past interest due on the profits for the seventeen years, and Erickson gave Parker a "bond"15 for the amount of the profit balance, with interest. Later, Erickson asked Parker to accept boards as payment, at least in part, again reflecting the shortage of cash, but Parker refused. He did advise Erickson that a man by

\footnotetext{
${ }^{14}$ Nowhere is an interest percentage mentioned in the "Minutes," but this is not unusual since it was fixed by Statute at seven percent at this time. Samuel Neville, New Jersey Laws, I (Trenton: State of New Jersey, I 739), 245.

${ }^{15}$ The term "bond" as used throughout the manuscript is best described as "a deed whereby the obliger obligates himself, his heirs, executors or administrators to pay a certain sum of money on a day appointed." Black's Law Dictionary, $4^{\text {th }}$ ed. (St. Paul: West Publishing Company, 1951), pp. 661-662.
} 
the name of Randolph at Amboy would take whatever boards he would send. Erickson's will reveals a meager estate, so it is obvious that he did not fare very well in the partnership.

Such arrangements and much of the accounting done then would not be considered a satisfactory systematic record by even the simplest professional standards of today. But they are not dull; there is considerably more charm in them than the current IBM card.

For those with an interest in cost-of-living, there is a complete record of the expenses of apprenticing Elisha's youngest brother, Lewis Johnston Parker, to a Mr. Provoost ${ }^{16}$ in New York, and of his clothing and other furnishings for the two year period of the "Minutes." One might well suspect, however, that Lewis was enjoying a considerably better standard of living in New York than most apprentices.

Arbitration involving a third, disinterested party is recounted in five different Entries, beginning with one on April 6, I 748. Parker had brought suit against Moses Burgess, who had had a judgment rendered against him in favor of the Parker estate. Burgess protested that the sheriff had not delivered the summons in connection with the action against him for rent of a meadow, and consequently he had never heard of the court action. Burgess contended that, had he known, he could have proved that the rent had been paid as agreed on (with Elisha's mother before her death) and there would have been no damages found by the jury. Burgess suggested that Edward Antill, an affluent property owner in the New Brunswick area and Council Member at the time, should determine a reasonable amount. Parker had no objections, since Antill was a family friend and a muchrespected man in the community. As a result of the arbitration, Burgess paid approximately eight pounds less than the court had demanded. As a matter of record, the payments were actually made by a third party, John Smyth, who probably owed money to Burgess and discharged his obligation by having Parker credit Burgess's account. ${ }^{17}$ This procedure was typical.

${ }^{16}$ Another daughter of the Alexanders, Mary, was married to a John Provoost, merchant, in New York. One might speculate that this was a Parker relative by marriage to whom Lewis was apprenticed. There is no positive evidence, since only the last name is given.

17 "Minutes," Entry of March 26, $175^{\circ}$. 
Multiple transactions that seem baffling today were apparently perfectly well understood then by even the humblest people, at least sufficiently well to have protected their interests. Under date of April 20, I 748, Elisha records a five-way credit arrangement:

... bill of Costs due from Ezekiel Bloomfield, which Bloomfield had been refusing to pay, he always Pretending he Stood Charged for it in Mr. Lyells books, \& that he believ'd he had paid it. To day I settled Mr. Lyells Acct. with [him] and he fell a triffle in his debt for which See his book and he now gives me an Order on J. Smyth to Pay me Seven Pounds and two Pence in full of Said Costs. It's in his Action Against John Johnston. It Seems John Smyth has a bond of his in Suit \& is to Pay me when he Recovers the money of Sam Crow-

The "contingency" problems of such crediting are evident in another entry of April 8, r 748:

Spoke to John Deare about his Note to Jennett Parker-he Says Dunster had Money of his in his hands and haveing an Accot: agt: the Estate of John Parker it was Agreed that Dunster Should Credit said Accot: to the Amount of the Note. but as the Accot: with Dunster Remains Unsettled the Note for That Reason is not yet given up.

In terms of opening the books to debtors or creditors in disagreement, there are many instances recorded by Elisha. On one such occasion, which Elisha entered on April IO, I 748, he noted as follows: I this day went to him [Heard] again about Settling.--by my father's books there appears to be a ballce: of about $\mathfrak{f}_{50} \mathrm{o}$. - in his favour but Heard shewed me his book and in it many Charges particularly one of $\mathfrak{f}_{\mathbf{1}} 6$. paid to Col. Ogden $-\mathfrak{E}_{4}$. odd for disbursemt: \& many others I Don't Remember that are not Creditted in my Father's hooks. - and I observe by his book that he has Kept verry Little Credit, that my father gives himself Credit for many Articles not mentioned in Heard's book,-I believe the Charges in Heards book will att ballce: (or Rather more than ballce) what's against him in my fathers books -but this I only guess at for the Accot: Appeared to be So Confus'd \& the dates of the Articles so old that it Almost made me give over any farther thoughts of Settling.

I am not however at Present at Leisure to Attend such a troublesom Piece of Work as it must be.

Under the date of May 23, I 748, a man by the name of Wright Skinner came to Elisha to settle his bond and brought in an account against John Parker's estate for work done amounting to $\mathrm{Eg}$. I 5, done in the year I730, eighteen years before. Elisha honored the bill. 
Although his debt to the Parker estate was subject to interest, Wright Skinner does not appear to have suggested that interest be paid on his long-outstanding account.

The preceding examples attest to colonial accounting principles and the operation of multiple-credit arrangements to offset the currency shortage. But the "Minutes" also reflect the larger efforts and innovations of the colony, together with their consequences.

All students of the American colonial scene have noted the scarcity of English money even though most of the financial business was calculated in terms of British pounds, shillings, and pence. The connection with England gave the colonies their basic money system, yet trade with the mother country drained them of their gold and silver coin. The colonists bought more than they sold; as a result they shipped to English creditors the precious metals they received in trading with Spanish America, the West Indies and southern Europe. England prized her colonies for the hundreds of thousands of pounds sterling with which they supplied her in coins and bullion annually.$^{18}$ In spite of the many proposals by the colonists that England make some provision for coinage in the colonies, she steadfastly refused.

New Jersey experimented during the period I 668-I 709 in an effort to keep coins in the colony. In I 685 the East Jersey Assembly raised the nominal values of all coins, discovered that it did not have the desired effect and repealed the Act in the same year. ${ }^{19}$

Queen Anne issued a Proclamation in 1704 that foreign coins should not be valued more than one-third higher in the colonies than they were in England. Such money became known as "Proclamation Money." "20 Unfortunately, most colonies already had a higher rate of inflation than the Queen allowed and to obey would have produced a depression. Massachusetts took the lead in defying the royal order, by refusing to make any grants for the support of the local government unless the money appropriated bore the former (and higher) provincial rate. Therefore, American colonies, with the

${ }^{18}$ Curtis P. Nettels, Money Supply of the American Colonies Before ${ }_{1720}$ (Madison, Wisconsin: University of Wisconsin, 1934), pp. I 72-175.

19 Ibid., p. $24 \mathrm{I}$.

20 Ibid., p. 242. 
exception of Maryland, Barbados and Virginia, persisted in overvaluing coins.

The Proclamation alone could not compel an individual to refuse coin that was over-valued, nor did it provide meaningful punishment. Thus, in I708, an Act of Parliament was passed (to be effective May I, I 709) imposing a fine of $\hat{E}$ ro or imprisonment of six months for paying or receiving coin in discharging debts if the coin exchanged bore a higher value than the Proclamation rate. The new law was as successfully evaded as the Proclamation. In I 709, the New York Assembly voted taxes and fixed the value in standard pieces of eight valued at eight shillings an ounce, so that there could be no mistake about their intentions to continue over-valuing. ${ }^{21}$

After I 709, the inflationary movement took another direction into the field of paper money. In New Jersey, the first issue in I 709 was brought about by a request to finance an expedition against Canada. ${ }^{22}$ The treasury was empty; no funds had been voted in three out of the previous six years. Three thousand pounds of paper money were issued and were to be retired by taxes in two years. New Jersey made this money legal tender.

In I 723, the first New Jersey Loan Office Law (Public Land Bank Law) was passed. ${ }^{23}$ It was the nearest approach to the idea of a commercial bank that appeared in colonial times. Elisha's father served as one of the Loan Bank Commissioners, and from the "Minutes" we know that the notes issued were at "Proclamation Money" rates. $^{\mathbf{2 4}}$

Against this financial background, it is easy to understand Elisha Parker's constant, careful reference to "eight shillings the ounce" or "province" money in his journal. He wanted to be certain that payment of debts would be made at the same rate as when contracted. The issue had become a live one again in 1740 , when the colonists had begun pressing for issuance of another $\hat{t}_{40,000}$ of Bills of Credit against the determined stand of the Governors, who were attempting

${ }^{21}$ Nettels, Money Supply, p. 246, fn. 34 .

${ }^{22}$ Donald L. Kemmerer, "History of Paper Money in New Jersey," Proceedings of the New Jersey Historical Society, New Series, LXXIV (Newark: New Jersey Historical Society, 1956), i по.

${ }^{23}$ L. H. Gipson, British Empire Before the American Revolution, III, Northern Plantations (Caldwell, Idaho: Caxton Printers, Ltd., 1936), 141.

${ }^{24}$ See Elisha Parker's "Minutes," original pagination, $6 \mathrm{I}$. 
to abide by their instructions that none be issued without prior Crown approval. ${ }^{25}$ Since all of the colonies acted independently, the value of money fluctuated from province to province. Elisha carefully noted payments in York [New York] money and the equivalent in New Jersey money. In general, New York money was the most stable of all the colonies. However, compared with colonies such as Rhode Island, Massachusetts, or South Carolina, New Jersey's was also stable.

An entry of April I 3, r 749, is indicative of the problems of dealing with differences in monetary value:

Received of John Rino in part of his and Jonas Greenway bond to my Mother Ten Pound Sixteen Shillings \& ten Pence

I rec'd it in pa. of $8 / 25$ \& took them at $8 / 8$ P.P; because Rino took them so. but they in fact Come to but $£_{10.15 .4}$ so I lose I $8 \mathrm{~d}$.

The years $\mathrm{I} 745$ to $\mathrm{I} 748$ were filled with disturbances and riots over land titles, particularly in the Elizabethtown patent area. The underlying controversy had begun long before in 1672 , when the Proprietors had first tried to collect quit-rents. ${ }^{26}$ The charter to the Duke of York had mentioned quit-rents and so did Governor Richard Nicolls, who granted the half million acres in the Monmouth and Elizabethtown patent on October 28, 1664. Nicolls gave permission to an association of English residents on Long Island to purchase land for a plantation. When John Baker, John Ogden, John Bayly, Luke Watson and their other members paid the Indians 40 fathoms of white wampum for the property, Nicolls confirmed it, and included the following clause:

... rendering and paying Yearly unto the Duke of York or his assigns a certain Rent according to the customary Rate of ye Countery for New Plantations and Doing and Performing such Acts and Things as shall be appointed by his said Royal Highness or his Deputy. . . . 27

Nicolls had established certain arrangements for the acquisition of land, including purchase from the Indians, recording of it before the Governor, no town planting before Indian purchase, no separate

${ }^{25}$ Kemmerer, "History of Paper Money," pp. I 10-120.

26 The quit-rent was a relic of the old feudal food and labor (or service) dues which had evolved into an annual money payment.

${ }^{27}$ Rev. Edwin F. Hatfield, History of Elizabeth, New Jersey; Including the Early History (New York: Carlton \& Lanahan, 1868), p. 32. 
contracts with any Sachem, and the following very important concession:

Purchases were to be free of all manner of Assessments 5 years after their town platt is set out, and when 5 years are expired they shall only be liable to rates and payments according to the custom of other inhabitants both English and Dutch. ${ }^{28}$

Planting had already begun by June, I 665. In the meantime, unknown to Nicolls because of the slow communication between England and America, the Duke of York had conveyed title to Carteret and Berkeley on June 24, I 664. There was no word of this until June I 3, I 665, when Philip Carteret arrived in Newport News, Virginia, and wrote Nicolls that he would be in New York in five or six days. Actually, he arrived in New York July 29, I665. A distant relative of Lord Carteret, Philip, had been appointed a deputy and had come with Robert Vauquellen, a French surveyor from Caen, together with a company of some thirty people. When Carteret arrived there were mutual explanations and examination of documents. Tradition has it that Carteret admitted that the land was lawfully purchased from the natives and thus confirmed that the grant by Governor Nicolls some four months after its sale to Carteret and Berkeley had a valid title. ${ }^{29}$

The Monmouth settlers used delaying tactics to avoid the payments of quit-rents and taxes, but the Elizabethtown patentees seemed to be more volatile people and violence was more often the pattern. ${ }^{\mathbf{3 0}}$ An entry of August I6, I 749, mentions a John Wade (or Waid) who leased a Parker Plantation in Somerset County between First and Second Mountain, then called the "Blew Hills" [the Watchungs], in partnership with a Thomas Abbott. It may have been a second generation Wade, a freeholder in Elizabethtown, who signed a petition to the King, dated July, I 744, describing the petitioners as faithful and loyal subjects and complaining about conflicting land titles which were

... occasioning writs of Trespass and Leases of Ejectment on behalf of the

${ }^{28}$ Ibid., p. 33 .

${ }^{29}$ Hatfield, History of Elizabeth, p. $5 \mathrm{I}$.

${ }^{30}$ John Pomfret, The Province of East New Jersey: $1609-1702$ (Princeton, New Jersey: Princeton University Press, 1962), pp. 152-335. 
said pretended Proprietors, many being turned out of their freeholds and large bills of costs taxed against them. ${ }^{31}$

It is obvious that over the years the position of the Proprietors had changed from that of Captain Philip Carteret in I 665, if tradition is correct. The Proprietors, including James Alexander and Andrew Johnston, were objecting to the patentees cutting timber on land that did not belong to them and to their claiming land which had been surveyed and distributed to them with complete disregard to the rights of the original Proprietors, their assigns or heirs.

In I 7 I 4, the first of a series of test cases was tried, involving the so-called Clinker Lot Division of the Elizabethtown Tract, Vaughan v. Woodruff. ${ }^{32}$ The Proprietors won that case. The next, in I 730 , Lithgow v. Robinson, lasted for nineteen consecutive hours and the Chief Justice summed up the evidence at five A.M. The Clinker Lot men won this case and the courage of the Elizabethtown men was renewed.

Subsequent cases obscured this decision and the issue remained essentially undecided. In I 745, the Elizabethtown Bill was brought up by the Proprietors through the aid of James Alexander, with the expectation that Governor Morris would sit as Chief Justice and render a favorable decision. When Morris died in I 746, the matter was allowed to stand. Jonathan Belcher was the next Governor and he was much too neutral to risk a decision under his guidance, in the opinion of the Proprietors. It is quite probable that Elisha Parker of the "Minutes," was involved in these legal actions, as attorney for the Proprietors beginning in 1745 .

In 1747 , the Assembly and Council appointed a committee to consider the best means to suppress the riots at Elizabethtown and elsewhere, as they were spreading, and Elisha Parker was chosen for this committee. ${ }^{33}$ Since he was attorney for the Proprietors, no doubt he was expected to serve their interests. He must have been an unpalatable choice to many, since he had no doubt been instrumental in issuance of the complained-of writs of ejection which were being brought against the so-called "squatters."

One must suspect a policy of delay on the part of the Assembly.

${ }^{31}$ Monnette, First Settlers, I, 47.

32 Osgood, American Colonies, IV, 27-28.

${ }^{33}$ New Jersey Archives, First Series, VI, 393-394. 
No meetings were held for over a year, in spite of the urging of the Council. It was obvious that the Assembly was procrastinating because of their sympathy for the Elizabethtown men. It would not appropriate funds to strengthen the militia in order to make it effective and to prevent the kind of jailbreaks that were occurring. Governor Belcher tried to arrange for test cases, but the Assembly turned a deaf ear, thinking that the courts were weighted in favor of the propertied men. The British government had ruled that it was a matter for the courts to settle. However, the matter was never settled that way. In I 75 I, a "Reply to a Bill in Chancery of New Jersey," drawn by William Smith, was filed by the Elizabethtown men in answer to the Bill of $\mathbf{I} 745$, but no action was ever taken. The fourth Colonial War was on the horizon and defense problems obscured the land riot issue. As time passed, the public disturbances gradually subsided. ${ }^{34}$

There is clear evidence that the Parkers had owned land in the disputed Elizabethtown patent area, which the Johnstons, as Executors of John Parker's will, had sold. An entry of April 23, I 750, notes that Elisha executed a bond with his brother, James, to David Sutton:

Condn. to Pay back the Considr: money \& of 67 Acres of land by him Purchas'd of my Fathers Execut:- in Case the land should be taken from him by Reason of any Defect of my fathers title. The Considr. is 160 . .- the Intent of the bond was to Satisfy him as to the Elizabethtown Claim, the land it Seems lying within what they Pretend to be their Right —and as the Executors do not give Warranty-I made him a Promise at the time of his takeing the deed - to Execute such bond when I came of Age-\& he lately Put me in mind of that Promise.

In addition to these large-scale disputes, there were always minor problems of title, arising from lack of proper surveying, failure to record changes of title, or human error. The entry of April 24, I 749 is amusing with respect to lots purchased by Elisha of Woodbridge. Apparently the first person who bought a lot from that tract settled on the wrong lot and all the rest followed suit, "by which means they are all wrong settled," as Elisha put it. Several entries involve an affair of land at Cranbury [Elisha spelled it Cranberry], which Eli-

\footnotetext{
${ }^{34}$ An account of the Elizabethtown land problems is also documented in Osgood, American Colonies, IV, 24-37.
} 
sha's father, John, had arranged to have purchased for him by a silent agent, Robert King, a good family friend. This arrangement was made while John Parker was a Commissioner of the Loan Office and may have involved land on which a loan was being foreclosed. Ethically, and perhaps legally, Parker could not make the purchase himself. In any event, he permitted the land to be used by the mother of Francis Hollinshead. In the years after John Parker's death, Hollinshead came to assume the land was his own and sold it to Patrick Vance. The effort to straighten out this unclear title fell to Elisha.

Beyond the value of the manuscript as a reflection of the monetary, political and land title problems of the period, and as an example of the accounting principles of the time, there is much genealogical material. The journal illustrates the Parker family's rapid rise to an aristocratic status in society. No valuation of the estate is made by Elisha, but in approximately half of the fifty-six or so mortgages or notes outstanding, the original obligations are mentioned and they total about $\dot{t} 532$. This would be a small portion of the estate. The wills support the surmise that the Parkers were wealthy in land and in their lending operations, judging by property descriptions and by annual incomes from various sources which are bequeathed in the wills for specific purposes. ${ }^{35}$ Their interests were with the Council, not the Assembly, and it is no surprise to learn that the Revolutionary years brought problems of loyalty to them. Their close friends, the Skinners and the Antills, were Loyalists and both fought in the Loyalist Regiment. James Parker, the surviving son, chose the path of neutrality. He deftly walked the political tight-rope in those touchy years, taking himself to Hunterdon County, and avoiding partisan activities. He was jailed for a month or two because of his Tory connections. However, after the war he returned to Perth Amboy and resumed his business. He became Mayor of Perth Amboy and was one of the few whose property was not confiscated. ${ }^{36}$

Whether Elisha Parker became solely responsible for the estate in consideration of the fact that in 1748 he was now twenty-four years

\footnotetext{
${ }^{35}$ Original manuscript wills: Elisha Parker, Liber BB I59-160, John Johnston, Liber LBB $320-324$.

${ }^{36}$ Collections of the New Jersey Historical Society: Loyalists of New Jersey, X, 298. See also Benedict, New Brunswick, p. 256.
} 
old, or whether he was given a power-of-attorney to handle these matters is not clear. However, that he handled the estate with a considerable amount of business acumen is clear. Certainly he ultimately expected to share in it and would have been motivated to be conservative. Yet there is an innate sense of fairness in his transactions, particularly in his recognition that in some business handled by his mother there might well be error and the benefit of the doubt went to the debtor. Apparently she made many informal arrangements, or failed to record such. In such cases, Elisha consulted with Mr. Andrew Johnston, or worked out an arrangement himself. The bond to David Sutton guaranteeing the Elizabethtown title was more than the executors of the estate had been willing to give, it would appear.

But Elisha was not sentimental about the business. There is ample evidence that sentimentality did not dissuade him from suing to recover funds from a widow or two who could not pay (Entry April I 4, I748 and Entry, April I6, I 748), nor from proceeding against a Mr. Morlatt, for example, a man he, himself, described as being "exceeding poor" (Entry, August I I, I 749).

The last entry in the "Minutes" is dated December 26, I750. In I 75I, just six years after his promising return to Perth Amboy, Elisha Parker died and, ironically, he had left no will." "Consumption" had put an abrupt end to what might well have been a brilliant career. Since he and Catherine Alexander Parker had had no children, Elisha left to posterity only a sketchy diary and his "Minutes."

${ }^{37}$ There are different dates given for Elisha's death, but probably the correct one is I $75 \mathrm{I}$, according to the Inventory filed by his wife, Catherine. There is a record of the original notice to the widow by Jonathan Belcher, ordering her to render an accounting by April 20, 1752 and signed by Thomas Bartow, Registrar. Liber 2531, 2532 LBE $5 \times 4$. Archives, State House, Trenton, New Jersey.

The Proceedings of the New Jersey Historical Society, New Series, V, I I, shows Elisha's birth as 1724 and death date as Mar. 14, 1757. But this date of death has a question mark and makes a reference to Singleton's Social New York, pp. 73, 302, 340. Parker in America, previously cited, supports the date of death as $175 \mathrm{I}$. 